\title{
X-AND Y-CHROMOSOME-SPECIFIC VARIANTS \\ OF THE AMELOGENIN GENE ALLOW \\ NON-INVASIVE SEX DIAGNOSIS FOR THE DETECTION OF PSEUDOHERMAPHRODITE GOATS
}

\author{
Renáta FÁBIÁN ${ }^{1,2}$, András KovÁCS ${ }^{1,3}$, Viktor STÉGER ${ }^{1}$, Krisztián FRANK ${ }^{1}$, \\ István EGERSZEGI ${ }^{2}$, János OLÁH ${ }^{3}$ and Szilárd BODÓ ${ }^{1,2^{*}}$ \\ ${ }^{1}$ National Agricultural Research and Innovation Centre, Szent-Györgyi Albert u. 4, \\ H-2100 Gödöllő, Hungary; ${ }^{2}$ Szent István University, Gödöllő, Hungary; \\ ${ }^{3}$ University of Debrecen, Debrecen, Hungary
}

(Received 13 July 2017; accepted 6 November 2017)

The Polled Intersex Syndrome (PIS) is responsible for the absence of horns in homozygous and heterozygous goats causing a female-to-male sex reversal in the homozygous polled genotypic female (XX) goats. A simple and efficient non-invasive method was elaborated to detect the genotypic sex from hair and faecal samples using a pair of primers to amplify the X- and Y-linked alleles of the amelogenin gene. The PCR products were easily distinguishable using agarose gel electrophoresis: we detected an X-specific single band in samples originating from healthy phenotypic females and double (X- and Y-) bands in samples from males. The new PCR method is applicable for diagnosing the sex of PISaffected animals already as newborn kids, in contrast with the phenotypic findings appearing only after puberty, and thus it may replace the cumbersome chromosome investigations. amelogenin

Key words: Goat, sex determination, intersex, Polled Intersex Syndrome,

The goat (Capra aegagrus f. hircus) is an important livestock animal in agricultural production for multiple purposes. There were world-wide efforts to create a polled goat breed, but all of them failed because of the growing proportion of hermaphrodite and male pseudohermaphrodite kids and the absence of homozygous polled females. According to Asdell's (1944) hypothesis the increasing number of phenotypic male and hermaphrodite kids and the shifted sex proportion were caused by XX sex reversal in the case of homozygous genetic females. This was corroborated later by chromosome investigations (Basrur and Kanagawa, 1969). The phenotypic variability in these individuals is the consequence of a complex mechanism of the sexual differentiation process in which

*Corresponding author; E-mail: bodo.szilard@gmail.com; Phone: 0036 (28) 526-100/4144; Fax: 0036 (28) 526-151 
the gene-dose effect and some molecular factors play a critical role (Uhlenhaut and Treier, 2006). The Polled Intersex Syndrome (PIS) mutation is caused by a microdeletion (11.7 kbp DNA) undetectable by light microscopy on chromosome 1 (1q43). The deletion includes both the FOXL2 gene needed for ovary formation and the PISRT1 gene responsible for horn formation (Laurent et al., 2014). Male pseudohermaphrodites cannot be distinguished by their phenotype from normal males before puberty. It would be important to have a quick, easy, non-invasive and reliable method for diagnosing the genetic sex of PIS-affected newborn animals instead of the cumbersome cytogenetic method.

The non- and minimally invasive sample collection methods were elaborated in the last century. Faecal samples can be collected easily and have the potential for obtaining a large sample size with minimal disturbance of the animals; however, they provide DNA of low quality and small quantity (Waits and Paetkau, 2005) and may be contaminated by microorganisms or digested food items (Maudet et al., 2004). Polymerase chain reaction (PCR) methods are useful for sex identification even from faeces or hair of low quality. In the event of any mass fatality incident, DNA analysis plays a vital role in the identification of disaster victims. Teeth are one of the most resistant structures in the human body that resist decomposition, which makes them the prime choice for extracting DNA to identify individuals. PCR analysis targeting regions of the amelogenin gene has become the method of choice for sex determination using biological samples.

In the present experiments we used amelogenin primer pairs for sex determination. The amelogenin gene exists on both the $\mathrm{X}$ and the $\mathrm{Y}$ chromosomes, and encodes a protein important in the development of the mammalian tooth and enamel matrix. This gene is located in a conserved region among vertebrates (Murphy et al., 2003). Differences in the length of the sequence have been observed between $\mathrm{X}$ - and $\mathrm{Y}$-specific amelogenin genes in a variety of species. Therefore, the X-Y homologues of the amelogenin gene may be suitable for sex determination on the molecular level (Weikard et al., 2006; A-qin et al., 2007). We studied the efficacy of using a PCR with amelogenin primers for sex diagnosis in pseudohermaphrodite goats.

\section{Materials and methods}

\section{Preparation of DNA samples from faecal, hair, blood and muscle tissue samples}

Faecal, hair and blood samples were collected from 5 polled intersex (4 hermaphrodites and 1 pseudohermaphrodite), 9 male and 5 female goats. Genomic DNA was obtained from faecal samples by ISOLATE Fecal DNA Kit (Bioline). As a first step, a homogeneous sample was created from a single faecal pellet using liquid nitrogen, and from this $0.15 \mathrm{~g}$ to $0.40 \mathrm{~g}$ samples were used for 
DNA isolation according to the manufacturer's instructions. Genomic DNA from hair was obtained by digestion with proteinase K using the QIAamp DNA Investigator Kit (QIAGEN) according to the manufacturer's instructions. Blood samples were taken from the jugular vein into 5-mL EDTA-tubes and the genomic DNA was isolated with the QIAamp DNA Investigator Kit (QIAGEN) according to the manufacturer's instructions. Muscle tissue samples were collected from slaughtered normal male and female goats, and were used as control because of the poor quality and low quantity of DNA from the hair and faecal samples. Genomic DNA was extracted from meat samples using the QIAamp DNA Investigator Kit (QIAGEN) according to the manufacturer's instructions. DNA concentrations in all samples were evaluated by reading their absorbance at $260 \mathrm{~nm}$ in a UV-VIS spectrophotometer (Nanodrop, Thermo Scientific). The amount of DNA from faecal samples was almost the same as that obtained from blood and muscle tissues, but the DNA isolated from a single hair was less than that obtained from other sources $(20-32 \mathrm{ng} / \mu \mathrm{L})$; however, the purity of the DNA was normal (A260/280: 1.7-1.8). The DNA samples isolated from faecal samples had a little less value than normal spectra in which the A260/280 ratios were 1.4-1.6 and the DNA concentration was between 70 and $100 \mathrm{ng} / \mu \mathrm{L}$.

\section{PCR amplification}

The X- and Y-chromosome-linked AMELX and AMELY genes were chosen as markers for sex identification, because this gene exists on both the $X$ and the $\mathrm{Y}$ chromosomes. Bovine amelogenin primers SE47 and SE48 (Ennis and Gallagher, 1994) were chosen and aligned to the goat reference X chromosome (GenBank accession number CM001739) using BLAST (Altschul et al., 1990). The PCR primers were designed for the coordinates $120,249,873$ to $120,249,892$ 5'-CTCCATGACTCCAACCCAAC-3' and for the coordinates $120,250,163$ to $120,250,183$ 5'-ACTTCTTCCCGCTTGGTCTT-3'. PCRs were conducted in a total reaction volume of $25 \mu \mathrm{L}$ containing $1 \mathrm{x}$ Phusion HF Buffer, $0.4 \mathrm{U}$ Phusion HS II DNA Polymerase, $200 \mu \mathrm{M}$ of each dNTP and $3.5 \mu \mathrm{M}$ of each primer. In the case of faecal, blood and muscle samples, $60 \mathrm{ng}$ DNA template was used for each PCR, while in the case of hair samples, because of their lower DNA content, $6 \mu \mathrm{L}$ DNA template (20-32 ng) was used regardless of the concentration. PCR amplification was conducted in a ProFlex PCR System thermal cycler (Applied Biosystems) at an initial denaturation of $98^{\circ} \mathrm{C}$ for $30 \mathrm{sec}$, followed by 35 cycles of $98{ }^{\circ} \mathrm{C}$ for $10 \mathrm{sec}, 62.5^{\circ} \mathrm{C}$ for $10 \mathrm{sec}$ and $72{ }^{\circ} \mathrm{C}$ for $2 \mathrm{~min}$, with a final extension step at $72{ }^{\circ} \mathrm{C}$ for $5 \mathrm{~min}$. PCR products were stained with $6 \mathrm{x}$ Loading Dye and determined by electrophoresis in a $2 \%$ agarose gel containing ethidium bromide at $10 \mathrm{~V} / \mathrm{cm}$. The product sizes were determined with the help of GeneRuler 100bp Plus DNA Ladder (ThermoFisher Scientific). 


\section{Results}

From all of the 19 faecal, muscle tissue, blood and hair samples we obtained DNA of sufficient quantity and quality for the PCR reaction. As expected, PCR amplification of the amelogenin gene resulted in a single band (310 bp) for female samples, and two bands ( $310 \mathrm{bp}$ and $250 \mathrm{bp}$ ) for the male samples. Figure 1 shows the results of PCR sexing of 12 DNA samples after agarose gel electrophoresis.

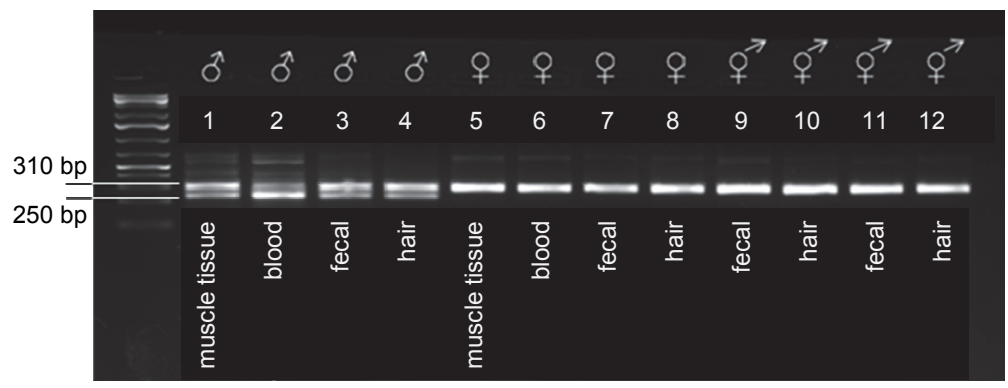

Fig. 1. Agarose gel electrophoresis after sex PCR of the DNA extracted from muscle, hair, blood and faecal samples. Sexing of hermaphrodite, pseudohermaphrodite and known-gender goats using PCR assays based on the amelogenin gene. Male muscle tissue, blood, faecal and hair samples $(1,2,3,4)$ presented 250-bp and 310-bp bands, while female samples $(5,6,7,8)$ had only 310-bp bands. The faecal and hair sample from the hermaphrodite $(9,10)$ and the pseudohermaphrodite

$(11,12)$ goat presented only 310 -bp bands, as did the female samples

In the faecal and hair samples $(11,12)$ of the PIS homozygote, phenotypically buck only the X-chromosome-specific PCR product was detectable, so the animal was diagnosed as a genetic female. In this experimental study a total of 19 samples were tested and 5 goats were considered hermaphrodites. In the case of the healthy male and female controls all PCR sex determinations were in line with the phenotypic sex of the goats, indicating that the sexing method based on the PCR-amplified amelogenin gene was correct and reproducible. According to the sex PCR results this method proves to be a suitable new future diagnostic method to detect the presence of the Polled Intersex Syndrome immediately after birth.

\section{Discussion}

In this study we have established a simple and accurate method to detect the X-and Y-chromosome-specific sequences of the amelogenin gene, amplified with a newly applied single primer pair. The reaction resulted in an X-specific product which was present in each sample, and a Y-specific product in samples containing the Y-chromosome. As the goat amelogenin gene is located on both the $\mathrm{X}$ and the $\mathrm{Y}$ chromosomes, differences in their length are observed between 
the $\mathrm{X}$ - and $\mathrm{Y}$-specific genes. There is a diagnostic difference of $60 \mathrm{bp}$ within the amplified region, so the male and female cytogenetic sex is easily detectable. Using this method, sex identification is applicable for defining the genetic sex of infertile polled goats at a very young age, already as male pseudohermaphrodite kids, in contrast with the phenotypic findings that appear only after puberty. For the routine breeding practice, the use of a non-invasive sampling method for genetic studies is preferable. Thus we suggest collecting faecal and hair samples, because the applied DNA isolation and PCR method can be used efficiently for sex detection.

\section{Acknowledgements}

This research was funded by $8526-5 / 2014 /$ TUDPOL. The authors wish to thank Mrs. Éva Fehér goat breeder and Mrs. Judit Bordán for sample collection.

\section{References}

Altschul, S., Gish, W., Miller, W., Myers, E. and Lipman, D. (1990): Basic local alignment search tool. J. Mol. Biol. 215, 403-410.

A-qin, C., Zi-rong, X. and Song-dong, Y. (2007): Sexing goat embryos by PCR amplification of Xand Y-chromosome specific sequence of the amelogenin gene. Asian-Aust. J. Anim. Sci. 20, 1689-1693.

Asdell, S. A. (1944): The genetic sex of intersexual goats and probable linkage with the gene for hornlessness. Science 99, 124.

Basrur, P. K. and Kanagawa, H. (1969): Anatomic and cytogenetic studies on 19 hornless goats with sexual disorders. Ann. Génét. Sél. Anim. 1, 349-378.

Ennis, S. and Gallagher, T. F. (1994): A PCR-based sex determination assay in cattle based on the bovine amelogenin locus. Anim. Genet. 25, 425-427.

Laurent, B., Maelle, P., Laurence, G., Aurelie, A. B., Maeva, E., Daniel, L. B., Nathalie, D., Christophe, R., Corinne, C., Norbert, B. G. and Eric, P. (2014): FOXL2 is a female sexdetermining gene in the goat. Current Biolog. 4, 404-408.

Maudet, C., Luikart, G., Dubray, D., Von Hardenberg, A. and Taberlet, P. (2004): Low genotyping error rates in wild ungulate feces sampled in winter. Mol. Ecol. Notes 4, 772-775.

Murphy, M. A., Waits, L. P. and Kendall, K. C. (2003): Influence of diet on faecal DNA amplification and sex identification in brown bears (Ursus arctos). Mol. Ecol. 12, 2261-2265.

Pourjafar, M., Badiei, K., Sharifiyazdi, H., Naghib, M. S., Chalmeh, A. and Divar, M. R. (2012): Application of hormonal and single multiplex PCR assays for detection of freemartinism in a horned goat. J. Fac. Vet. Med. 38, 175-181.

Schmidt, D., Ovitt, C. E., Anlag, K., Fehsenfeld, S., Gredsted, L., Treier, A. C. and Treier, M. (2004): The murine winged-helix transcription factor Foxl2 is required for granulosa cell differentiation and ovary maintenance. Development 131, 933-942.

Uhlenhaut, N. H. and Treier, M. (2006): Foxl2 function in ovarian development. Mol. Genet. Metab. 88, 225-234.

Waits, L. P. and Paetkau, D. (2005): Non-invasive genetic sampling of wildlife. J. Wildl. Manage. 69, 1419-1433.

Weikard, R., Pitra, C. and Kühn, C. (2006): Amelogenin crossamplification in the family bovidae and its application for sex determination. Mol. Reprod. Dev.73, 1333-1337. 